\title{
Malwina Wolak
}

Uniwersytet Ekonomiczny we Wrocławiu

e-mail: malwina.wolak@ue.wroc.pl

\section{METODY PROGNOZOWANIA SPRZEDAŻY W PRZEDSIĘBIORSTWIE FARMACEUTYCZNYM}

\section{THE METHODS OF SALES FORECASTING IN THE PHARMACEUTICAL COMPANY}

DOI: $10.15611 /$ pn.2017.471.40

JEL Classification: C53, M41

Streszczenie: Proces prognozowania często wzbudza wiele wątpliwości co do jego zasadności. Wskazanie odpowiedniej metody, która pozwoli na zbudowanie precyzyjnej prognozy, jest procesem wieloetapowym. Celem artykułu jest zaprezentowanie wyselekcjonowanych metod prognozowania sprzedaży na przykładzie wybranego preparatu farmaceutycznego. Do osiągnięcia założonego celu zastosowano metody ilościowe: metodę naiwną, model Wintersa oraz metodę jakościową: opinie kierownictwa. Jednoczesne wykorzystanie tych metod do ustalenia prognozy końcowej badanego produktu umożliwia uzyskanie bardziej precyzyjnych szacunków oraz uwzględnienie wielu różnorodnych czynników determinujących prognozę sprzedaży. Specyfika rynku farmaceutycznego kreuje potrzebę przełożenia uwarunkowań tego sektora na dobór właściwych metod prognozowania sprzedaży, co wymaga indywidualnego podejścia zarówno do pojedynczych preparatów, jak i grup produktów. Każda sytuacja prognostyczna może odróżniać się od pozostałych, dlatego należy rozpatrywać je oddzielnie i zwracać uwagę na wszystkie czynniki determinujące daną prognozę sprzedaży.

Słowa kluczowe: prognozowanie sprzedaży, metody prognozowania, modele prognostyczne.

Summary: The process of forecasting often raises a lot of doubts as to its legitimacy. The indication of an appropriate method to build a precise forecast is a multi-stage process. The aim of this article is to present selected methods of forecasting sales on the example of a chosen pharmaceutical preparation. Quantitative methods have been used to achieve the goal: the naive method, the Winters model as well as the qualitative method: the management opinion. Using these methods simultaneously to determine the final forecast of the product under investigation makes it possible to obtain more precise estimates and to take into account various factors that determine the sales forecast. The specificity of the pharmaceutical market creates the need to translate the sector's determinants into the right sales forecasting methods, which require individual approaches for both: an individual product and product groups. As each prognostic situation may be different, it should be considered separately and attention should be paid to all the factors that determine a given sales forecast.

Keywords: sales forecasting, methods of forecasting, forecasting models. 


\section{Wstęp}

Prognozowanie jest niezbędne w procesie zarządzania przedsiębiorstwem, gdzie większość decyzji podejmowana jest w celu osiągnięcia przyszłych korzyści. Tworzeniu planu biznesowego służą głównie prognozy sprzedaży, które uznawane są za jedne z najważniejszych prognoz w organizacji.

„Potrzeba prognozowania w przedsiębiorstwie wynika z dwóch zasadniczych powodów: niepewności przyszłości i opóźnienia w czasie między momentem podjęcia decyzji a wynikłymi z niej skutkami” [Dittmann 2000, s. 15]. Mając dostęp do informacji o zmieniającym się otoczeniu, można korzystnie oddziaływać na skuteczność podejmowanych decyzji. Duże znaczenie mają informacje o charakterze prospektywnym, które pozwalają uzupełnić zbiory danych i ułatwiają podejmowanie decyzji dotyczących działalności przedsiębiorstwa, m.in. takich jak: określenie wielkości kapitału obrotowego, zatrudnienie odpowiedniej ilości siły roboczej, utrzymanie zapasów na właściwym poziomie, ustalenie planu i logistyki na produkcji, wyznaczenie planu sprzedaży i poziomu cen, jak również przydzielenie budżetu marketingowego na poszczególne produkty i inne działania promocyjno-sprzedażowe [Hill, Rieser 1993, s. 118]. Podejmowanie decyzji, które dotyczą przyszłości organizacji, bez wcześniejszego przewidywania spodziewanej sytuacji rynkowej i własnych wyników jest obarczone dużym ryzykiem. To ryzyko wynika z konieczności poniesienia dużych nakładów finansowych, czasu i pracy na wytworzenie produktów, a w przypadku niemożności ich sprzedaży przedsiębiorstwo zostanie narażone na straty finansowe, a nawet upadłość [Hajdas, Kowal, Woźniczka 2014, s. 152].

Konstruowanie precyzyjnej prognozy jest procesem wieloetapowym, mającym na celu wskazanie odpowiedniej metody prognozowania sprzedaży, na podstawie której zostanie wyznaczona prognoza końcowa. Celem artykułu jest zaprezentowanie wyselekcjonowanych metod prognozowania sprzedaży dla wybranego preparatu farmaceutycznego, produkowanego przez polskie przedsiębiorstwo produkcyjno-handlowe sektora farmaceutycznego. Rynek farmaceutyczny ma swoiste cechy odróżniające go od pozostałych sektorów, a relacje między sprzedażą oraz działaniami marketingowymi, a także zróżnicowanie kanałów dystrybucyjnych i odbiorców przekazu marketingowego kreują potrzebę przełożenia uwarunkowań tego sektora na proces zarządzania sprzedażą, tym samym proces prognozowania sprzedaży. W procesie badawczym wykorzystano zarówno metody ilościowe, jak i jakościowe, co pozwala na uwzględnienie wielu różnorodnych czynników determinujących sprzedaż danego preparatu na polskim rynku farmaceutycznym.

\section{Pojęcie i budowa prognoz sprzedaży produktów}

Prognoza sprzedaży jest wskazywana jako jedno z podstawowych narzędzi w zarządzaniu przedsiębiorstwem, przez co stała się przedmiotem wielu badań i rozważań. Bogata literatura przedmiotu dostarcza wiele definicji tego pojęcia. Zdaniem E.J. 
Davisa prognoza sprzedaży bazuje na prognozach, przewidywaniach i uwarunkowaniach rynkowych, które zostały poddane dogłębnej weryfikacji i analizie przeprowadzonej przez specjalistów, ze szczególnym naciskiem na czynniki nieuwzględnione w analizie ilościowej [Davis 1988, s. 4]. M.W. Johnston i G.W. Marshall, uzupełniając tę definicję, zwracają uwagę na fakt, że prognoza sprzedaży jest wyrażona wartościowo lub w jednostkach sprzedaży, może być wykonana dla określonego produktu lub dla całej linii produktów oraz w odniesieniu do rynku - jako całości lub dowolnej jego części. Ponadto prognozy sprzedaży mogą być również konstruowane dla grupy klientów, obszaru geograficznego czy też różnych okresów. Przytaczani autorzy zwracają uwagę na fakt, że prognozy sprzedaży uwzględniają szczegółowy plan marketingowy, zatem jeżeli proponowany plan zostanie zmieniony, to prognozowana sprzedaż także powinna ulec zmianie [Johnston, Marshall 2003, s. 128]. P. Dittmann, powołując się na definicje P. Benneta i W. Stantona, określa prognozę sprzedaży jako zbiór działań, który: ,[...] opisuje przewidywany poziom sprzedaży przedsiębiorstwa na wybranych rynkach docelowych, w określonym przedziale czasu, wyznaczony na podstawie sprecyzowanego w strategii marketingowej marketingu mix i przyjętych hipotez dotyczących sposobu oddziaływania czynników otoczenia marketingowego przedsiębiorstwa na wielkość sprzedaży" [Dittmann 2000, s. 23]. Przytoczone definicje prognozowania sprzedaży dowodzą, jak szczególną

Tabela 1. Proces budowy prognozy - etapy

\begin{tabular}{|c|l|l|}
\hline $\begin{array}{c}\text { Nr } \\
\text { etapu }\end{array}$ & \multicolumn{1}{|c|}{ Nazwa etapu } & \multicolumn{1}{|c|}{ Elementy składowe etapu } \\
\hline 1 & $\begin{array}{l}\text { Sformułowanie zadania } \\
\text { prognostycznego }\end{array}$ & $\begin{array}{l}\text { zjawisko, cel budowy prognozy, zmienna } \\
\text { prognozowana, okres prognozy, horyzont prognozy, } \\
\text { interwał prognozy, wymagania dotyczące dokładności } \\
\text { prognozy ex ante }\end{array}$ \\
\hline 2 & $\begin{array}{l}\text { Określenie przesłanek } \\
\text { prognostycznych }\end{array}$ & $\begin{array}{l}\text { przesłanki prognostyczne (założenia, hipotezy), } \\
\text { postawa prognosty (pasywna, aktywna) }\end{array}$ \\
\hline 3 & $\begin{array}{l}\text { Zebranie, obróbka i eksploracyjna } \\
\text { analiza retrospektywnych danych } \\
\text { prognostycznych }\end{array}$ & $\begin{array}{l}\text { gromadzenie odpowiednich danych, statystyczna } \\
\text { obróbka danych, eksploracyjna analiza danych }\end{array}$ \\
\hline 4 & $\begin{array}{l}\text { Wybór metody prognozowania } \\
\text { metoda prognozowania, reguła prognozowania, model } \\
\text { prognostyczny, koszt prognozy }\end{array}$ \\
\hline 5 & $\begin{array}{l}\text { Konstrukcja prognozy sprzedaży } \\
\text { budowa modelu prognostycznego, wyznaczenie } \\
\text { prognozy }\end{array}$ \\
\hline 6 & $\begin{array}{l}\text { Ocena dopuszczalności prognozy } \\
\text { sprzedaży }\end{array}$ & $\begin{array}{l}\text { stopień niepewności/dopuszczalność prognozy, błąd } \\
\text { ex ante, błąd ex post, wiarygodność prognozy, słowna } \\
\text { ocena }\end{array}$ \\
\hline 7 & Zastosowanie prognozy sprzedaży & wdrożenie ostatecznej prognozy - prognozy końcowej \\
\hline 8 & Ocena trafności prognozy sprzedaży & weryfikacja prognozy i formułowanych ex ante opinii \\
\hline
\end{tabular}

Źródło: opracowanie własne. 
rolę odgrywają w zarządzaniu przedsiębiorstwem. Wielkość i struktura sprzedaży wpływają przede wszystkim na poziom i strukturę produkcji, poziom przychodów ze sprzedaży oraz wynik na sprzedaży. Determinują także poziom kosztów: wytworzenia, ogólnego zarządu i sprzedaży [Nowak 2016, s. 287].

Konstruowanie prognozy sprzedaży powinno być postrzegane jako proces, podczas którego wraz z napływem nowych danych, informacji, opinii, wyników badań następuje ocena przydatności wybranej metody prognozowania. Należy być także przygotowanym na adaptację zmian zachodzących w prognozowanym zjawisku, jak na przykład w sprzedaży. Budowa prognozy sprzedaży jest procesem sekwencyjnym, przebiegającym według ustalonego schematu prognostycznego zamieszczonego w tabeli 1 [Dittmann i in. 2011, s. 22-36; Dittmann 2000, s. 24-32].

Właściwie sporządzona prognoza sprzedaży zwiększa jakość planowania, tym samym budżetowania sprzedaży i wpływa na pomyślność w realizacji celów organizacji postrzeganej jako całości.

\section{Metoda prognozowania jako kluczowy element w procesie budowy prognozowania sprzedaży}

Proces prognozowania często wzbudza wiele wątpliwości co do jego zasadności. Prognozując wielkość sprzedaży, należy zwrócić szczególną uwagę na dobór właściwych metod i modeli prognostycznych, które powinny być dostosowane do specyfiki sektora oraz potrzeb danego przedsiębiorstwa. Ponadto trzeba pamiętać, że nie ma możliwości dysponowania całkowitą wiedzą na temat nabywców, a wzmożone działania konkurencji mogą oddziaływać na zmniejszenie efektów zaplanowanych działań promocyjno-sprzedażowych w danym przedsiębiorstwie. Dodatkowo warunki rynkowe oraz otoczenie marketingowe ulegają ciągłym przeobrażeniom, co niewątpliwie wpływa na trafność sporządzanych prognoz.

Horyzont czasowy prognozy sprzedaży może dotyczyć różnych okresów. Im dłuższy jest okres prognostyczny, tym trudniej przebiega proces prognozowania i pojawia się większe prawdopodobieństwo popełnienia błędu. Zazwyczaj wyróżnia się trzy okresy [Hajdas, Kowal, Woźniczka 2014, s. 153]:

- prognozy krótkoterminowe (nie więcej niż 12 miesięcy);

- prognozy średnioterminowe (od 1 do 3 lat);

- prognozy długookresowe (od 3 lat).

Metoda prognozowania sprzedaży to nie tylko sposób konstruowania prognozy sprzedaży, to także sposób przetworzenia informacji o przeszłości badanego zjawiska sprzedaży oraz sposób płynnego przejścia od przetworzonych informacji do prognozy sprzedaży. Budowa formalnego lub myślowego modelu prognostycznego pozwala na przetworzenie danych o przeszłości, odwzorowując w ten sposób zachowanie się rzeczywistego zjawiska, na przykład takie jak kształtowanie się wielkości sprzedaży w przeszłości. Jest to odwzorowanie uproszczone, jednak zachowujące kluczowe cechy badanego zjawiska - trend, wahania sezonowe i in. [Dittmann 2000, s. 33]. 
Na metodę prognozowania sprzedaży składa się model i reguła prognozowania. Reguła prognozowania to sposób, który pokazuje, jak przejść od informacji przetworzonej do prognozy sprzedaży. Bardzo często spotykaną i stosowaną regułą jest reguła podstawowa. Na podstawie tej reguły prognozę otrzymuje się poprzez ekstrapolację modelu poza zebrany zbiór danych, na podstawie którego budowano model. Należy tu zaznaczyć założenia, że model jest aktualny w okresie, którego dotyczy konstruowana prognoza. W odniesieniu do modelu regresji liniowej reguła podstawowa przyjmuje postać reguły prognozy obciążonej. Zgodnie z tą regułą prognoza na okres $t>n$ jest wartością oczekiwaną zmiennej prognozowanej w okresie $t$. Jeśli pojawią się uzasadnione przypuszczenia, że zaobserwowane odchylenia zmiennej prognozowanej od uzyskanych z modelu wartości teoretycznych mają szansę utrzymać się w przyszłości, to często stosuje się regułę podstawową z poprawką [Czerwiński, Guzik 1980, s. 111], w myśl której można uzyskać prognozę poprzez korektę prognozy wyznaczonej na podstawie reguły podstawowej. Podczas korygowania prognozy powinno się uwzględnić błędy poprzednich prognoz, jak również uwzględnić pominięte czynniki w modelu prognostycznym. Kolejną regułą jest reguła największego prawdopodobieństwa, prognozą wówczas jest stan zmiennej, gdzie istnieje największe prawdopodobieństwo realizacji, czyli wartość modalna - dominanta. $Z$ kolei reguła minimalnej straty bazuje na założeniu, że należy przyjąć taki stan zmiennej, którego realizacja przynosi najmniejsze straty [Cieślak (red.), 2000, s. 37].

Model prognostyczny sprzedaży ma za zadanie odwzorować prawidłowości zaobserwowane w przeszłości lub przyszłości, które wystąpią w prognozowanym zjawisku, a także musi obejmować zależności pomiędzy prognozowanym zjawiskiem a innymi zjawiskami i wpływającymi na nie czynnikami, np. kształtowanie się przychodów ze sprzedaży produktów farmaceutycznych.

Tabela 2. Klasyfikacja metod prognozowania sprzedaży ilościowe i jakościowe

\begin{tabular}{|l|l|}
\hline \multicolumn{2}{|c|}{ METODY PROGNOZOWANIA } \\
\hline \multirow{3}{*}{ ILOŚCIOWE } & Modele szeregów czasowych \\
\cline { 2 - 3 } & Modele ekonometryczne \\
\cline { 2 - 3 } & Modele analogowe \\
\cline { 2 - 2 } & Modele zmiennych wiodących \\
\cline { 2 - 2 } & Modele analizy kohortowej \\
\cline { 2 - 2 } & Testy rynkowe \\
\hline JAKOŚCIOWE & Opinie sprzedawców \\
\cline { 2 - 2 } & Opinie kierownictwa \\
\cline { 2 - 2 } & Opinie ekspertów \\
\cline { 2 - 3 } & Badania intencji nabywców \\
\hline
\end{tabular}

Źródło: opracowanie własne na podstawie [Dittmann 2000, s. 34]. 
Jedna z najczęściej występujących w literaturze klasyfikacji metod prognozowania to podział na ilościowe i jakościowe, co zostało przedstawione w tabeli 2.

Wybór odpowiedniej metody prognozowania, a także poprawne jej zastosowanie jest niezwykle ważnym zagadnieniem przy konstruowaniu prognozy. Jest to związane z tym, że dane metody są zasadne nie we wszystkich sytuacjach, przez co należy rozpatrywać je indywidualnie i zwracać uwagę na wszystkie czynniki wpływające na badane zjawisko, które determinuje prognozę.

\section{Prezentacja wybranych metod prognozowania sprzedaży i ich modeli prognostycznych dla preparatu farmaceutycznego $\mathrm{X}$}

Powszechnie znany rynek farmaceutyczny niewątpliwie jest jednym z najprężniej rozwijających się rynków w Polsce. Jak pokazują dane rynkowe, wartość rynku aptecznego w 2016 r. wyniosła 31,7 mld zł i wzrosła $+6,2 \%$ względem roku 2015 [www 1]. Szacuje się, że w latach 2016-2021 rynek apteczny w Polsce będzie przyrastał w tempie $+4,8 \%$ rocznie [www 2]. Ponadto rynek farmaceutyczny w styczniu 2017 r. odnotował sprzedaż na poziomie $3022 \mathrm{mln}$ PLN. Ta wartość wobec stycznia 2016 r. jest wyższa o blisko $+17,6 \%$, a względem grudnia 2015 wzrosła $+2,9 \%$ [www 3]. W ostatnich latach Polska stała się bardzo atrakcyjnym rynkiem zbytu także dla międzynarodowych koncernów farmaceutycznych. Ponadto rozwój nowoczesnych technologii, wzrastająca konkurencja rynkowa i powiększająca się paleta produktów farmaceutycznych, dostosowana do bieżących i nowych potrzeb klienta, przyczyniają się do rozwoju tego sektora.

Przedmiotem studium przypadku będzie wybrany preparat farmaceutyczny X, produkowany przez polskie przedsiębiorstwo produkcyjno-handlowe sektora farmaceutycznego. Jest to lek wydawany bez recepty (OTC). Klasyfikując ten preparat względem budowy i czynności organizmu, to jest on zaliczany do grupy (klasy) leków stosowanych w leczeniu chorób układu trawiennego [Michalik, Mruk, Pilarczyk 2014, s. 100-101]. Preparat wspiera pracę wątroby celem eliminacji szkodliwych substancji w organizmie. Tradycyjnie jest stosowany w leczeniu objawów niestrawności. Sprzedaż preparatu X głównie kształtują uwarunkowania rynkowe i konkurencja rynkowa, ponieważ nie jest wspierany przez producenta działaniami marketingowo-sprzedażowymi. Jednym z czynników, który determinuje sprzedaż tego preparatu, jest sezonowość. Zwiększona sprzedaż zauważana jest zwykle w okresie świątecznym [www 4], kiedy największym powodzeniem cieszą się ,[...] specyfiki otrzymywane z ostropestu, karczocha, zawierające kwas dehydrocholowy, cholinę, witaminy z grupy B. Mają one najczęściej działanie żółciopędne, regulują poziom tłuszczu i cholesterolu. Niektóre składniki jak sylimaryna czy cholina zapewniają integralność i stabilizowanie błon komórkowych w wątrobie, mają działanie odtruwające. Kwas dehydrocholowy jest pomocny we wzdęciach, bólu brzucha, odbijaniu i zaparciach" [www 5]. W analizie sprzedaży w latach 2014-2016 oprócz wspomnianych wahań sezonowych pojawiły się także sporadyczne wahania przypadkowe, które mogły 
być spowodowane na przykład chwilowym brakiem produktów konkurencyjnych na rynku. Sprzedaż wybranego leku X z hurtowni do aptek wyrażoną w sztukach przedstawia rys. 1 .

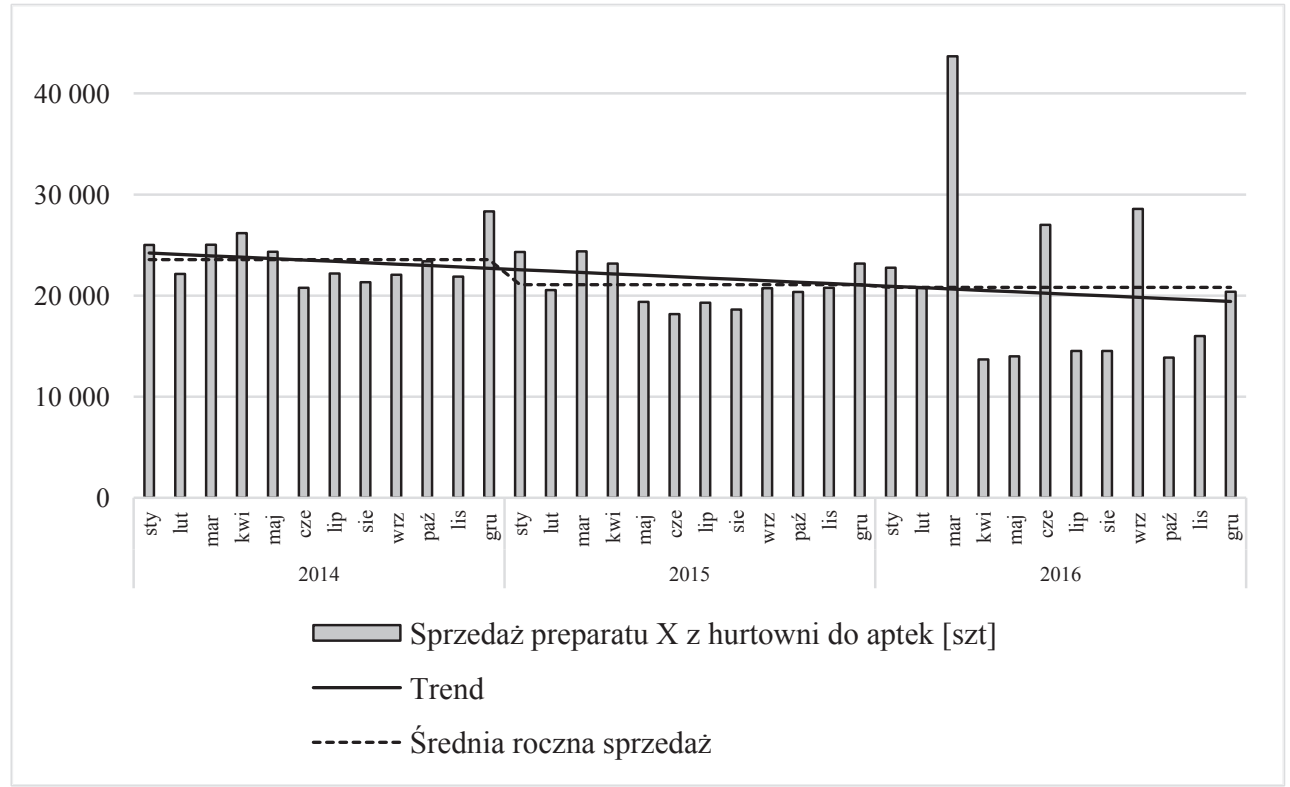

Rys. 1. Sprzedaż leku X z hurtowni do aptek w latach 2014-2016 (szt.)

Źródło: opracowanie własne.

Wskazanie odpowiedniej metody, która pozwoli na zbudowanie precyzyjnej prognozy, jest procesem wieloetapowym, mającym na celu skonstruowanie prognoz badawczych zarówno tych ilościowych, jak i jakościowych, aby spośród wszystkich prognoz badawczych wyznaczyć tę właściwą, czyli prognozę ostateczną sprzedaży. Zanim jednak nastąpi etap konstruowania prognozy, to należy wyselekcjonować odpowiednie metody prognozowania sprzedaży, które będą dopasowane do specyfiki sektora farmaceutycznego, danej klasy preparatu, a przede wszystkim samego preparatu. Dla badanego leku X zostaną zaprezentowane następujące metody prognozowania:

- metoda naiwna, będąca metodą ilościową - modele szeregów czasowych;

- model Wintersa, będący metodą ilościową - modele szeregów czasowych;

- opinie kierownictwa - metoda jakościowa.

Metoda naiwna jest rekomendowana do sporządzenia prognozy sprzedaży, która będzie punktem odniesienia dla innych prognoz sprzedaży, sporządzonych bardziej zawansowanymi metodami, oraz oceny celowości stosowania innych metod prognozowania. Metody naiwne to ilościowe metody prognozowania na podstawie szeregu czasowego ze stałym poziomem zmiennej prognozowanej. Znajdują swoje 
zastosowanie przy prognozach krótkookresowych - kilka tygodni, kwartał, półrocze, maksymalnie do roku. Są powszechnie stosowane ze względu na uniwersalność, ich prostotę i niski koszt stosowania. Na podstawie historycznych danych sprzedażowych badanego preparatu X można założyć, że wahania przypadkowe są rzadkie i niewielkie (np.: październik 2014, czerwiec 2016, wrzesień 2016) oraz nie zmieni się wpływ czynników kształtujących sprzedaż, a wówczas sprzedaż przedsiębiorstwa np. w następnym kwartale, półroczu będzie kształtować się na dotychczasowym poziomie, można skonstruować prognozę na jeden kolejny okres $t$, czyli $t=n+1(n-$ ostatnia obserwacja zmiennej prognozowanej). Dwa środkowe kwartały roku są ewidentnie kwartałami o stałej wielkości sprzedaż. Wahania sezonowe pojawiają się w okresie świąt: Boże Narodzenie i Nowy Rok (grudzień, styczeń) oraz Wielkanoc (17-21 kwietnia 2014 r., 2-6 kwietnia 2015 r., 25-28 marca 2016 r.), kiedy sprzedaż znacznie wzrasta. Wówczas prognozując metodą naiwną 1. i 4. kwartał roku, należy pamiętać, że będzie konieczna korekta otrzymanej prognozy kwartalnej, uwzględniająca dane sprzedażowe $\mathrm{z}$ analogicznego okresu poprzedniego roku.

Jedną z metod naiwnych, która jest powszechnie stosowana, jest konstrukcja prognozy na moment/okres $t$ na poziomie zaobserwowanej wartości zmiennej w momencie/okresie $t-1$ [Dittmann 2000, s. 57], czyli:

$$
y_{t}^{*}=y_{t-1},
$$

gdzie $y_{t}^{*}$ to prognoza sprzedaży wyznaczona na okres $t$, a $y_{t-1}$ to wielkość sprzedaży w okresie $t-1$. Ta metoda bazuje na modelu błądzenia losowego.

Inną formą tej metody jest prognozowanie sprzedaży oparte na analizie udziału w rynku. Zakładając, że ogólny popyt na wybrany produkt wzrośnie w następnym okresie o 20\% (sezon świąteczny) oraz że udział przedsiębiorstwa w rynku nie ulegnie zmianie, to można przewidywać, że prognoza sprzedaży będzie wskazywała na $20 \%$ wzrost sprzedaży w przedsiębiorstwie w następnym okresie.

Na podstawie danych sprzedażowych leku X możemy zaobserwować zarówno obecność trendu, jak i wahań sezonowych (okres świąteczny) oraz pojedyncze wahania przypadkowe (październik 2014, czerwiec 2016, wrzesień 2016). Obecność tych elementów warunkuje możliwość zastosowania modelu Wintersa. Jest to model z grupy modeli szeregów czasowych, czyli jest metodą ilościową. Prognozowanie na podstawie tego modelu jest metodą znacznie bardziej zaawansowaną niż metody naiwne. Znajduje zastosowanie tylko w przypadku kiedy pojawia się w badanym zjawisku trend oraz przede wszystkim wahania okresowe i przypadkowe. Występuje w dwóch wersjach: addytywnej i multiplikatywnej. W modelu addytywnym zakłada się, że wartość zmiennej prognozowanej jest sumą składowych szeregu czasowego, co znaczy, że między poszczególnymi składowymi szeregu nie występują składowe niezależne, tj. interakcje. Ponadto wartości każdej składowej wyrażone są w takich samych jednostkach miary co zmienna prognozowana. Podczas dekompozycji szeregu wahania cykliczne, sezonowe i przypadkowe przedstawia się jako odchylenia od trendu lub od stałego, przeciętnego poziomu zmiennej prognozowanej. Natomiast 
w modelu multiplikatywnym zakłada się, że wartości zmiennej prognozowanej są iloczynem składowych szeregu czasowego. W tej wersji tylko jedna ze składowych, trend lub stały, średni poziom prognozowanej zmiennej, wyrażana jest w jednostkach zmiennej prognozowanej jako odchylenia od trendu lub stałego, przeciętnego poziomu zmiennej [Dittman i in. 2011, s. 81-82].

W kontekście omawianego leku X zastosowanie znajduje addytywny model Wintersa, który zapisuje się następująco [Cieślak (red.) 2000, s. 76]:

$$
\begin{gathered}
F_{t-1}=\alpha\left(y_{t-1}-C_{t-1-r}\right)+(1-\alpha)\left(F_{t-2}+S_{t-2}\right), \\
S_{t-1}=\beta\left(F_{t-1}-F_{t-2}\right)+(1-\beta) S_{t-2}, \\
C_{t-1}=\gamma\left(y_{t-1}-F_{t-1}\right)+(1-\gamma) C_{t-1-r},
\end{gathered}
$$

gdzie:

$F_{t-1} \quad$ - odpowiednik wygładzonej wartości, która została otrzymana z prostego modelu wygładzania wykładniczego,

$S_{t-1} \quad$ - ocena przyrostu trendu na moment/okres $t-1$,

$C_{t-1}$ - ocena wskaźnika sezonowości na moment/okres $t-1$,

$r \quad$ - długość cyklu sezonowego/liczba faz,

$\alpha, \beta, \gamma$ - parametry modelu, które przyjmują wartość z przedziału $[0,1]$.

Równanie prognozy na moment/okres $t>n$ dla tej wersji modelu wygląda następująco: $\left.y_{t}^{*}=F_{n}+s_{n}(t-n)+C_{t-r}\right)$, gdzie $y_{t}^{*}$ to prognoza sprzedaży wyznaczona na okres $t$, a $n$ to liczba wyrazów szeregu czasowego zmiennej prognozowanej.

Budując prognozę sprzedaży w przedsiębiorstwie farmaceutycznym, należy mieć na uwadze fakt, że przedsiębiorstwo i jego otoczenie marketingowe oraz sektor farmaceutyczny ulegają ciągłym przeobrażeniom w czasie. $\mathrm{Z}$ tego powodu charakter i siła zależności między zmiennymi mogą się zmieniać. W efekcie model opisujący sprzedaż poszczególnych produktów farmaceutycznych stanie się nieaktualny. Przy tak dużej dynamice rynku farmaceutycznego znaczenia nabiera kolejna metoda - metoda jakościowa: opinie kierownictwa. Prognozę uzyskuje się w wyniku dyskusji, burzy mózgów, w której uczestniczą osoby mające wpływ na przyszłą sprzedaż, czyli osoby odpowiedzialne za zaopatrzenie, produkcję, kontrolę jakości, finanse, marketing. Celem tej metody jest uzyskanie możliwie jak najwięcej informacji na dany temat - w tym przypadku utrzymanie tendencji rozwojowej i dotychczasowego udziału rynkowego leku X. Doświadczenie tych osób pozwoli na uwzględnienie wszystkich pozostałych aspektów, których nie można było uwzględnić w prognozach ilościowych, np.: pojawienie się lub wycofanie z rynku innych konkurencyjnych leków lub suplementów diety, strategia dotycząca edukacji osób odpowiedzialnych za bezpośrednią sprzedaż (przedstawiciele apteczni i medyczni, hurtownie, farmaceuci) - w celu odświeżenia wiedzy na temat właściwości leczniczych leku X.

Zaprezentowane metody stosowane pojedynczo nie byłyby wystarczające, ponieważ każda z nich uwzględnia inne czynniki lub założenia determinujące prognozę sprzedaży, np.: 
- metody naiwne - stałość w oddziaływaniu czynników, udział rynkowy;

- model Wintersa - trend, wahania sezonowe, wahania przypadkowe;

- opinie kierownictwa - intensywne działania promocyjno-reklamowe konkurencji, nienormatywność lub brak surowca na rynku, zbyt wysoka lub niska temperatura powietrza stanowiąca utrudnienie dla procesu wytwórczego oraz magazynowania, zaplanowana promocja dla produktu komplementarnego do preparatu $\mathrm{X}$, zaplanowane remonty na hali produkcyjnej oraz przerwy w produkcji, $\mathrm{i}$ inne. Jednoczesne wykorzystanie powyższych metod ilościowych i jakościowej do ustalenia prognozy końcowej preparatu X pozwoli na bardziej precyzyjne szacunki i uwzględnienie wielu różnorodnych czynników, wpływających na sprzedaż leku X. Prognoza końcowa bazująca na tych metodach będzie w mniejszym stopniu obarczona błędami ex post niż każda z tych prognoz oddzielnie.

Skutki błędnego zaplanowania wielkości i struktury sprzedaży mogą być niezwykle dotkliwe dla działalności przedsiębiorstwa farmaceutycznego. Niewydolność w zaspokajaniu potrzeb klientów i związane z tym opóźnienie w dostarczaniu produktów farmaceutycznych może przyczynić się do ogólnego niezadowolenia, a w konsekwencji utraty części klientów, ponieważ pacjent musi się leczyć tu i teraz, a nie za kilka dni czy tygodni, kiedy dany produkt ponownie będzie dostępny. Następnie może pojawić się utrata pozycji rynkowej. Z kolei przy nadmiernej produkcji przedsiębiorstwo może mieć kłopot ze zbyciem wyrobów, co wpłynie na wzrost zapasów i kosztów ich magazynowania lub utylizacji, konieczność udzielania dodatkowych opustów czy rabatów, udzielania swoim klientom prolongaty na termin płatności, co finalnie może obniżyć kondycję finansową przedsiębiorstwa.

\section{Zakończenie}

Proces konstruowania prognozy sprzedaży powinien być wieloetapowy i mieć na celu skonstruowanie prognoz badawczych zarówno tych ilościowych, jak i jakościowych, wskazujących kierunki trendów sprzedaży na rynku i ich punkty zwrotne oraz określających opłacalność sprzedaży. Natomiast strategia przedsiębiorstwa, zawierająca hipotezy dotyczące oddziaływania otoczenia marketingowego organizacji na wielkość sprzedaży, powinna determinować wybór spośród wszystkich prognoz badawczych tej właściwej, czyli prognozy realistycznej - ostatecznej prognozy sprzedaży w organizacji.

Prognozowanie sprzedaży i działań sprzedażowo-marketingowe zarówno przez producentów, jak i hurtownie lub apteki wymaga swoistego podejścia oraz stosowania właściwie wyselekcjonowanych metod i modeli prognostycznych. Jest to spowodowane tym, że każda sytuacja prognostyczna może odróżniać się od pozostałych, przez co należy rozpatrywać je indywidualnie i zwracać uwagę na wszystkie czynniki determinujące prognozę sprzedaży. 


\section{Literatura}

Cieślak M. (red.), 2000, Prognozowanie gospodarcze: metody i zastosowanie, Wydawnictwo Naukowe PWN, Warszawa.

Czerwiński Z., Guzik B., 1980, Prognozowanie ekonometryczne: podstawy teoretyczne i metody, PWE, Warszawa.

Davis E.J., 1988, Practical sales forecasting, McGraw-Hill, London.

Dittmann P., 2000, Metody prognozowania sprzedaży w przedsiębiorstwie, Wydawnictwo Akademii Ekonomicznej im. Oskara Langego we Wrocławiu, Wrocław.

Dittmann P., Dittmann I., Szabela-Pasierbińska E., Szpulak A., 2011, Prognozowanie w zarządzaniu sprzedaża i finansami przedsiębiorstwa, Wolters Kluwer Polska, Warszawa.

Hajdas M., Kowal W., Woźniczka J., 2014, Zarządzanie marketingiem, Wydawnictwo Uniwersytetu Ekonomicznego we Wrocławiu, Wrocław.

Hill W., Rieser I., 1993, Marketing-Management, Paul Haupt AG Verlag, Bern.

Johnston M.W., Marshall G.W., 2003, Churchill/Ford/Walker's Sales Force Management, McGraw-Hill, Boston.

Michalik M., Mruk H., Pilarczyk B., 2014, Marketing strategiczny na rynku farmaceutycznym, Wolters Kluwer, Warszawa.

Nowak E., 2016, Rachunkowość zarzadcza w przedsiębiorstwie, CeDeWu, Warszawa.

[www 1] http://www.pharmaexpert.pl/aktualnosci/rynek-apteczny-w-2016-roku-krotkie-podsumowanie.html (23.02.2017).

[www 2] http://www.mp.p1/kurier/138858,rynek-farmaceutyczny-w-polsce-wzrost-w-tempie-5-wlatach-2016-2021 (23.02.2017).

[www 3] http://www.pharmaexpert.pl/media-files/PEX_PharmaSequence_podsumowuje_rynek_farmaceutyczny_stycze_2017.pdf (23.02.2017).

[www 4] http://www.panacea.pl/articles.php?id=2312 (4.03.2017).

[www 5] http://farmacja.smallpro.pl/wp-content/uploads/2014/02/farmacja-praktyczna-nr-4-42.pdf, s. $11(4.03 .2017)$. 